\title{
Diversity, Choice and the Quasi-market: An Empirical Analysis of Secondary Education Policy in England*
}

\author{
Steve BradLey and Jim TAYLOR
}

Department of Economics, Management School, Lancaster University, Lancaster, UK (e-mail: jim.taylor@lancaster.ac.uk; s.bradley@lancaster.ac.uk)

\begin{abstract}
This article investigates the extent to which exam performance at the end of compulsory education has been affected by three major education reforms: the introduction of a quasi-market following the Education Reform Act (1988); the specialist schools initiative introduced in 1994; and the Excellence in Cities programme introduced in 1999. Using a panel of schools for all state-funded secondary schools in England (1992-2006), we find that only about one-third of the improvement in school exam scores is directly attributable to the combined effect of these three major education reforms. The distributional consequences of the policy, however, are estimated to have been favourable, with the greatest gains being achieved by schools with the highest proportion of pupils from poor families.
\end{abstract}

\section{Introduction}

Over recent decades, and in countries as diverse as Australia, Chile, India, New Zealand, Sweden, the United States and the United Kingdom, governments have decentralized the provision of compulsory education in the hope of stimulating improvements in the educational attainment of pupils (Fiske and Ladd, 2000). The debate about the most appropriate method of providing education has a long history (Friedman, 1962) and has spurred a growing body of theoretical analyses (Hoxby,

\footnotetext{
*The authors thank the participants in seminars at Lancaster, Piacenza and Queensland Universities, the ICRIER in Delhi, IIT-Karagpur in Kolkata and two referees for helpful comments on an earlier draft. The authors are grateful to the Department for Children, Schools and Families (DCSF) for providing the data and to the Nuffield Foundation for supporting the research reported in this article. The authors alone are responsible for all errors and omissions.
}

JEL Classification numbers: I20, I21, I28. 
1998, 1999; Fernandez and Rogerson, 1999; Bearse, Glomm and Ravikumar, 2000; Nechyba, 2000; De Fraja, Oliveira and Zanchi, 2005; De Fraja and Landeras, 2006). In addition, a large number of empirical analyses have been undertaken, particularly in the United States of America. In both theoretical and empirical literatures, the critical issue is the trade-off between efficiency and equity (Bradley and Taylor, 2002). Those who oppose a decentralized approach to educational provision argue that it will lead to an increase in socioeconomic segregation and ultimately greater income inequality (Levin, 1991a, 1991b). It is also argued that the wider social benefits generated by education - such as citizenship, a deeper sense of community and knowledge spillovers - can only be internalized through centralized provision. In contrast, proponents of a decentralized system argue that decentralization is more likely to lead to an increase in allocative and productive efficiency (Hoxby, 1996). In addition, there is considerable disagreement over the effectiveness of resource-based education policy initiatives, especially those related to teaching inputs (Hanushek, 2003; Krueger, 2003).

In the United Kingdom, the education policy agenda has manifested itself in a series of education reforms across the entire school sector, beginning with the Educational Reform Act of 1988, which sought to stimulate the creation of a quasi-market in primary and secondary education. At the heart of these reforms were measures to increase parental choice and competition for pupils between schools. These quasimarket reforms have been accompanied by a substantial increase in expenditure on education since Labour came to power in 1997. At the secondary school level, total real expenditure increased by $60 \%$ from $£ 9.9$ billion in $1997 / 98$ to $£ 15.8$ billion in 2006/07, whereas real expenditure per full-time equivalent pupil has increased by over $50 \%$, from $£ 3,206$ in $1997 / 98$ to $£ 4,836$ in $2006 / 07$ (at 2005/06 prices). ${ }^{1}$

Two expenditure-based reforms have figured prominently in the secondary education sector in England. The specialist schools initiative was introduced in 1994 to increase the diversity of secondary education provision, thereby enhancing parental choice. In addition, in 1999 the Labour Government introduced the Excellence in Cities (EiC) initiative, which sought to improve the educational performance of pupils in secondary schools located in the most disadvantaged urban areas. The key distinguishing feature of this policy initiative was to provide more resources to schools with a high proportion of pupils from poor families and to stimulate cooperation between schools, in the context of partnership agreements, by sharing good practice (Kendall et al. 2005; Machin, McNally and Meghir, 2007).

Several previous papers have investigated the effects of the quasi-market in secondary education in England on exam results, school efficiency and equality of educational opportunity (Bradley and Taylor, 2002, 2004; Bradley, Johnes and Millington, 2001). More recently, Taylor (2007) has estimated the impact of the specialist schools initiative on examination outcomes. In the present article, we draw these previous strands of our research together to measure the impact of these three

\footnotetext{
${ }^{1}$ See DCSF, Annual Report 2007, p. 102 and Annual Report 2008, p. 150, annex N.
} 
education reforms on the change in exam performance in secondary schools over the period 1992-2006. Our focus is on the proportion of pupils who obtain five or more 'good' grades in the General Certificate of Secondary Education (GCSE) exams, which are taken by all pupils in England at age $16 .^{2}$ The proportion of pupils in England obtaining 'good' exam grades rose from 35.5\% in 1992 to $58.3 \%$ in 2006, a dramatic improvement. Our aim is to answer three questions: first, what fraction of this improvement in exam performance can be attributed to the education reforms identified before? Secondly, which of the three major education reforms have had the greatest impact in raising exam performance in secondary schools? Thirdly, have the reforms had any distributional consequences? For, instance, how do the effects of the education reforms vary by pupil composition in a school, such as family income and ethnicity?

To answer these questions, we use a panel of secondary schools covering the period 1992-2006, which has the advantage that we can take a medium-term view of the effect of the quasi-market reforms, the EiC programme and the specialist schools initiative. Moreover, by incorporating all three policy initiatives into our analysis, we are able to get a better feel for the relative importance of each policy reform since the early 1990 s through to 2006 . From a technical point of view, using a panel of schools allows us to control for school-level unobserved heterogeneity and so reduce the bias caused by endogeneous school choice.

The rest of the article is structured as follows. In section II, we briefly describe the education reforms that have led to the creation of the quasi-market in secondary education, the specialist schools initiative and the EiC programme. A brief review of previous empirical studies is provided. Section III introduces the data, identifies the determinants of school performance and presents our econometric methodology. Section IV discusses the results of a statistical analysis of changes in school performance over the period 1992-2006. Section V concludes.

\section{Choice and competition in secondary education}

\section{The introduction of a quasi-market in secondary education in England}

Over the last 20 years, the provision of education in Britain has been radically transformed by a series of reforms, many of which stem from the Education Reform Act (Department of Education and Science, 1988). These reforms have led to the creation of a quasi-market in secondary education (Le Grand, 1991, 1993; Glennerster, 1991). ${ }^{3}$ As a result, a centralized state model of educational provision has been replaced by a more decentralized approach. The salient institutional features of the quasi-market

\footnotetext{
${ }^{2}$ The GCSE is a standard, norm-based exam taken in approximately $8-10$ subjects by pupils normally aged 15-16. There are eight pass grades ranging from A* down to G. A 'good' grade is defined as being in the range $A^{*}-\mathrm{C}$. The government uses the proportion of pupils obtaining five or more $\mathrm{A}^{*}-\mathrm{C}$ grades in the GCSE exams as the benchmark for measuring a school's success. Grades $A^{*}-\mathrm{C}$ are considered acceptable for entry into university, together with passes in more advanced examinations (A and AS levels) 2 years later.

${ }^{3}$ Glennerster (1991) explains why the quasi-market is not a full market solution.
} 
in England's schools have been described elsewhere (Bradley et al., 2000). The two main tenets of the decentralized approach are greater parental choice over the school attended by their child and an increase in competition for pupils between schools. Parents may be expected to take a school's exam performance into account, among other factors, in deciding on an appropriate school for their child, thus increasing allocative efficiency through greater choice. ${ }^{4,5}$

Schools have an incentive to recruit pupils because funding is linked directly to pupil numbers, and allowing schools to determine their own allocation of funding was expected to result in greater productive efficiency. By allowing schools to compete for pupils, it was expected that educational performance would improve. Successful schools would thrive whereas unsuccessful schools would either close, become smaller or improve their own performance in response to competition. It is expected that schools are most likely to respond positively to competition from rival schools in the local quasi-market. Similarly, the greater the amount of choice available to parents in an education market place, reflected by the number of schools in the district, the stronger the competition effect should be.

The sorting of pupils between schools and cream-skimming by 'good' schools, however, could have distributional consequences. Pupils from poorer families may increasingly become concentrated in the 'poor' (i.e. worst-performing) schools whereas pupils from wealthier families become increasingly concentrated in 'good' schools. Cream-skimming by schools reinforces this process of segregation, insofar as schools which face an excess demand for places are more likely to 'select' those pupils with the best chance of being successful in national exams, thereby making the school more popular with potential entrants. In contrast, failing schools have little option but to accept less able pupils.

For the United States, there is a growing body of evidence that examines the effect on school performance of competition between state-funded schools (Borland and Howsen, 1992) and competition between school districts (Blair and Staley, 1995; Marlow, 1997, 2000; Zanzig, 1997). Gibbons, Machin and Silva (2006) review this evidence and conclude that it is at best 'mixed'. Furthermore, there is still very little empirical evidence for the United Kingdom (Levacic and Hardman, 1998). Bradley et al. (2000) tested to see if a quasi-market in the secondary education sector had been created, whereas Bradley, Johnes and Millington (2001) investigate the determinants of school efficiency. Both studies conclude that the greater the competition among schools, the larger the improvement in exam performance and efficiency. Moreover, 'good' schools have grown more rapidly and expanded their pupil capacity to accommodate the excess demand for places. Both studies focused on a fairly brief time

\footnotetext{
${ }^{4}$ Data from the Longitudinal Study of Young People in England (LSYPE) indicate that choice of secondary school is influenced primarily by family and friends $(66 \%)$, a school's location $(63 \%)$ and a school's exam performance $(38 \%)$. Other less important factors are religious considerations $(8 \%)$ and other characteristics of the school (7\%). It is worth noting that $86 \%$ of the parents indicated that their child went to their first-choice school.

${ }^{5}$ Information about each school's exam performance is provided by the annual publication of the School Performance Tables.
} 
period (1992-98), however, and it is possible that the quasi-market has become more effective as schools have adapted their behaviour over a longer time period.

More recently, Gibbons et al. (2006) have analysed the effect of choice and competition in the primary school sector within a $45 \mathrm{~km}$ radius of Central London using pupil-level data from the National Pupil Database. Choice and competition are measured by the number of schools in a district and the average distance between home and schools in the district. They find little evidence that choice and competition improve exam performance among English primary schools. Church schools do respond positively to competition, however, especially where their competitors are also church schools in more competitive markets. Moreover, the benefits of this competition are highest for pupils in church schools with a greater proportion of children from low-income families. The authors conclude that the effects of choice and competition in raising the exam performance of pupils in the primary school sector have not been substantial or widespread. These results also imply that choice and competition only have beneficial effects where there is heterogeneity among primary schools, in this case in terms of their religious background.

\section{The specialist schools initiative - increasing diversity and choice}

The second major education reform in the secondary school sector in England since the early 1990s has been the implementation of the specialist schools initiative. Specialist schools are state-maintained secondary schools with a designated subject specialism. Schools have had an incentive to acquire specialist status because they received a capital grant of $£ 100,000$ and extra funding of $£ 129$ per pupil for at least four subsequent years, thereby raising income per pupil by around 5\% a year. The policy began with the designation of technology colleges in 1994 and the government's aim was that all secondary schools in England would ultimately have specialist status (Levacic and Jenkins, 2004). The objective was to improve exam performance through greater subject specialization and hence greater choice. Moreover, since 2004, schools have been allowed to have two specialisms in any combination of subjects. ${ }^{6}$

There is conflicting evidence on the success of the specialist schools initiative. Evidence in support of a positive effect of specialist schools on exam performance is provided by Gorard (2002), Jesson (2002), Jesson and Crossley (2004) and OFSTED (2005). This evidence led the government to argue that the programme has been extremely effective in raising exam performance. This view has been challenged by the Education and Skills Committee of the House of Commons (2003, p. 4). Furthermore, Schagen and Goldstein (2002) have highlighted the methodological weaknesses of analyses that do not use multi-level modelling techniques and are especially critical of the school-level analyses conducted by the Specialist Schools Trust (see also Noden and Schagen, 2006). Taylor (2007) argues that previous research suffers from

\footnotetext{
${ }^{6}$ In 2006/07, $10 \%$ of all maintained secondary schools had two specialisms. See the Standards Site at the DCSF (http://www.standards.dfes.gov.uk/specialistschools/). Acquiring a second specialism extends the period over which the extra funding per pupil is provided.
} 
a serious weakness: no attempt has been made to investigate whether the switch to specialist status has been associated with a subsequent change in a school's performance over time.

\section{Excellence in Cities}

The EiC programme was a major government policy which aimed to raise the standard of education for young people from disadvantaged backgrounds in urban schools. The policy was launched in 1999 and was initially targeted at 471 secondary schools in 25 local education authorities in the major cities of England. The programme was extended in 2000 (351 schools in Phase 2) and again in 2001 (165 schools in Phase 3 ), eventually covering approximately one-third of all secondary schools organized into 57 partnerships (Kendall et al., 2005). ${ }^{7}$ The EiC aimed to diversify provision in secondary schools so that the needs of all pupils ('gifted and talented' as well as 'disadvantaged') were met in the context of cooperation between schools, organized through local partnerships. ${ }^{8}$ The objectives of the programme were to improve educational performance by raising the motivation and expectations of pupils, improving the quality of teaching and changing school ethos through partnerships to encourage cooperation between schools. ${ }^{9}$

A DfES-funded evaluation of the EiC programme, based on both qualitative and quantitative methods, concluded that the programme created a positive ethos towards learning in the recipient schools, resulting in improved pupil motivation and behaviour, and also better attendance (Kendall et al., 2005). These changes are regarded as important for subsequent improvements in exam performance. Kendall et al. (2005) show that there was an almost immediate impact of the EiC programme but this was confined to attainment in maths at the end of Key Stage 3 for pupils in the most disadvantaged schools. In a quantitative analysis, Machin, McNally and Meghir (2004) estimate that the EiC programme led to an increase of 3\% in the proportion of pupils moving up a grade. Much weaker effects were found for English, however, than for maths. In a more recent paper, Machin et al. (2007) investigate the distributional effects of the EiC policy, focusing on exam outcomes at age 14 (i.e. Key Stage 3). They find that the EiC policy increased the probability of a pupil attaining level 5 or above in more disadvantaged schools by 3.4 percentage points for those schools in Phase 1, falling to 2.4 percentage points for Phase 3 schools. Similarly,

\footnotetext{
${ }^{7}$ Expenditure on the EiC programme rose from $£ 24$ million in 1999/2000 to $£ 139$ million in 2000/01 and then to $£ 386$ million in $2005 / 06$. This represented approximately $4.3 \%$ of the total local authority current expenditure on secondary schools, which was $£ 9$ billion in 2000/01. Total funding of the EiC programme during 1999-2006 has been around $£ 1.7$ billion and the funding per pupil has been around $£ 140$ per pupil. See 'EiC 1999-2006' on the Standards Site, DCSF (http://www.standards.dcsf.gov.uk/sie/eic/).

${ }^{8}$ Specifically, the EiC programme established learning mentors, to provide support for students with educational and/or behavioural difficulties; learning support units, to provide short-term support for 'difficult to teach' pupils; and the gifted and talented programme. The latter has focused on the most able $5-10 \%$ of the pupils.

${ }^{9}$ See Excellence in Cities: The National Evaluation of a Policy to Raise Standards in Urban Schools 20002003 by Kendall et al. (2005) for a full discussion of the EiC programme.
} 
larger effects are observed for pupils of high or medium ability within more disadvantaged schools. Insofar as the positive effects of the EiC programme disseminate throughout the school over time, we might expect an improvement in exam performance of pupils in participating schools. Furthermore, this effect should be stronger for Phase 1 schools because there has been more time for good practice to be effective.

\section{Data and methods}

\section{The data}

The two main data sources used in the present study are the School Performance Tables, published annually by the Department for Children, Schools and Families (DCSF, formerly the DfES) and the unpublished annual Schools' Census. The School Performance Tables contain information about the exam performance of pupils (at school level) in all maintained secondary schools in England. The Schools' Census provides information on, for example, admissions policy, gender mix, the number of teaching and support staff, the pupil-teacher ratio, the proportion of pupils eligible for free school meals and with special educational needs. Data from these two data sets are available from 1992 through 2006, thus providing a consistent time series for our analysis. Additional information about specialist schools and schools involved in the EiC programme was obtained from the DCSF.

As explained before, school performance is measured here by the proportion of pupils obtaining five or more GCSEs at grades A* to C, which are defined as 'good' exam grades. ${ }^{10}$ This measure provides schools, parents and the government with a simple and readily understandable indicator of the exam performance of each school. Table 1 shows that there has been a sustained increase in the proportion of pupils obtaining 'good' exam grades. A primary advantage of this measure of exam performance is that it is available at school level from 1992 onwards, which means that it covers the entire period during which the education policies investigated in this article have been in operation. It is particularly useful for estimating the impact of the specialist schools initiative and the EiC programme as both these policies began after the start of the study period. We therefore have a pre-policy period that can be used as a control for estimating the post-policy effects.

\section{Econometric methodology}

Following Hanushek (1979, 1986), we estimate an education production function, which in its simplest form is as follows:

$$
Y_{s}=f\left(\mathrm{PUP}_{s}, \mathrm{FAM}_{s}, \mathrm{NEIGH}_{s}, \mathrm{SCH}_{s}\right)+\operatorname{error}_{s},
$$

\footnotetext{
${ }^{10}$ The correlation between the proportion of pupils obtaining five or more GCSEs at grades A*_C and exam performance measured by the average number of 'points' obtained per pupil (first made available in 1999) is 0.97 .
} 
where $Y$ is an educational outcome of school $s$ (e.g. exam results), PUP indexes observed pupil characteristics, FAM refers to family background factors, NEIGH indicates neighbourhood influences and SCH represents a set of school inputs, such as the pupil-teacher ratio. Given our focus on the effects of education policy on educational outcomes, equation (1) can be extended to include policy variables:

$$
Y_{s}=f\left(\mathrm{PUP}_{s}, \mathrm{FAM}_{s}, \mathrm{NEIGH}_{s}, \mathrm{SCH}_{s}, \mathrm{COMP}_{s}, \mathrm{SPEC}_{s}, \mathrm{EiC}_{s}\right)+\text { error }_{s} .
$$

Following the discussion in the previous section, three major policies directed at secondary schools are added to the model. The first is the competition between schools for pupils (COMP) which emerged from the creation of a quasi-market in education; the second is the specialist schools initiative (SPEC); and the third is the EiC programme.

Finding an appropriate measure of the degree of competition facing each school is not clear cut. The most obvious measure is an index of the extent to which pupils are concentrated in a district's schools, such as the Herfindahl index. ${ }^{11}$ Indices of concentration, however, are unlikely to be appropriate in the present context as they fail to capture the impact of changes in the competitive pressure facing schools over time. This is because measures of the concentration of pupils in a district's schools tend to be very stable from one year to the next simply because very few schools close or merge (see Table 1). Furthermore, schools face a trade-off between recruiting more pupils for financial reasons and maintaining their exam performance to ensure their competitive edge in the education market place. Hence, schools may be expected to engage in cream-skimming, whereby even non-selective (comprehensive) schools exercise some control over their admissions by attracting pupils likely to perform well academically.

A measure of competition used in a previous work (Bradley et al., 2000), which more closely reflects the dynamic and quality aspects of competition between schools, is their relative exam performance. To remain competitive in the local market for pupils, a school will strive to improve its own exam performance in line with improvements by its competitors. If a school's competitors are improving their exam scores at a faster rate than itself, the school is likely to suffer a decline in its share of the district's pupils. The primary variable driving a school's exam performance is therefore likely to be the exam performance of other schools in the same district. We consequently use the lagged mean exam score of all other schools in the same district as an indicator of the intensity of the competition for pupils facing individual schools. We also estimate the model using the lagged Herfindahl index as an alternative measure of competition in the regression analysis that follows.

The potential impact of the competition for pupils on a school's exam performance can also be investigated in other ways. First, an important feature of the quasi-market is the parental choice of school. We address this by stratifying our data according to the number of schools in a district as parental choice is likely to be greater in districts

\footnotetext{
${ }^{11}$ The Herfindahl index is the sum over all schools in a district of $s_{i}^{2}$, where $s_{i}$ is each school's share of the district's pupils.
} 


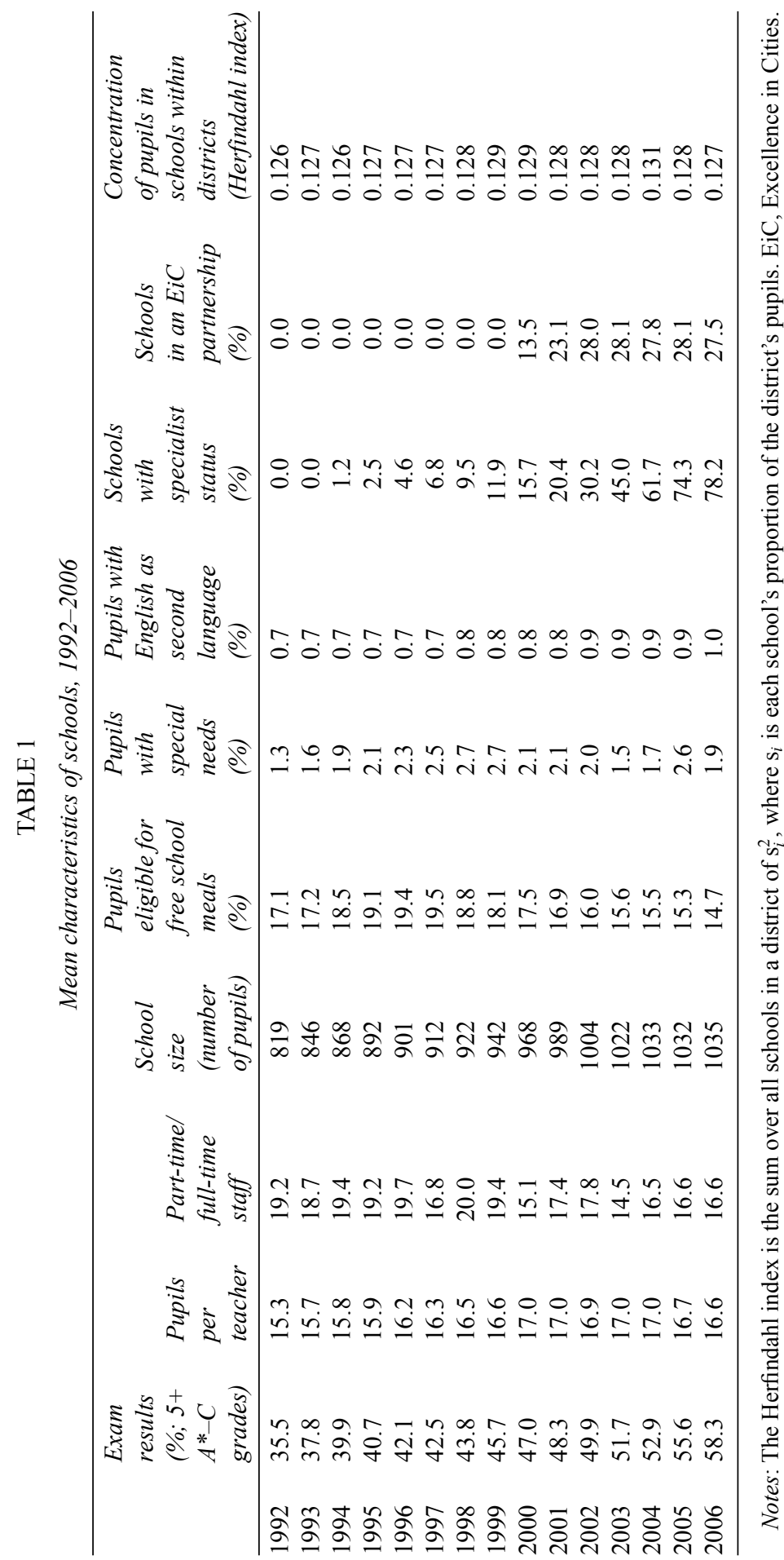

(C) Blackwell Publishing Ltd and the Department of Economics, University of Oxford 2009 
TABLE 2

Number of schools in each specialism in 2006

\begin{tabular}{llcr}
\hline Specialism & $\begin{array}{l}\text { Year specialism } \\
\text { introduced }\end{array}$ & Total in 2006 & $\%$ \\
\hline Technology & 1994 & 585 & 19 \\
Languages & 1995 & 221 & 7 \\
Arts & 1997 & 421 & 14 \\
Sport & 1997 & 350 & 11 \\
Business & 2002 & 229 & 7 \\
Engineering & 2002 & 57 & 2 \\
Maths & 2002 & 225 & 7 \\
Science & 2002 & 303 & 10 \\
Humanities & 2004 & 72 & 2 \\
Music & 2004 & 27 & 1 \\
None & & 588 & 19 \\
Total & & 3,078 & 100 \\
\hline
\end{tabular}

Source: Standards Site, DCSF (http://www.standards. dfes.gov.uk/specialistschools/).

with more schools. The district is used as the geographical education market as transport networks are important for secondary school pupils and these are based primarily on local authority districts. ${ }^{12}$ Secondly, we also use the Herfindahl index to stratify districts according to the degree of market concentration faced by schools.

SPEC is a dummy variable which is unity for those years during which a school has specialist status and zero otherwise; and similarly for the EiC programme. Therefore, for both SPEC and EiC we observe when the policy was 'switched on'. As suggested earlier, the existence of specialist schools adds to the diversity of educational provision in a district and hence allows pupils to choose schools that better match their preferences and aptitudes. To the extent that this choice improves allocative efficiency, we expect SPEC to have a positive effect on educational outcomes. However, there may be variation in exam performance between schools with respect to the subject in which they choose to specialize. This could occur, for example, if there are variations between subjects in the availability of suitably qualified teachers, such as in science and maths, or perhaps because the extra funding has a greater impact per student in some subjects than in others. Ten subject specialisms are identified in our statistical analysis (see Table 2).

The extra funding provided under the EiC programme was designed primarily to improve educational outcomes for pupils from disadvantaged backgrounds in urban areas. The funding was provided to support cooperation between schools so that best practice could be diffused and the exam performance of 'poor' schools improved. It

\footnotetext{
${ }^{12}$ There are 366 local authority districts in England. We also investigate an alternative measure based on the number of other schools within a specific radius of each school, thus allowing competition between schools across district boundaries (see footnote 25).
} 
is therefore expected that the $\mathrm{EiC}$ variable will have a positive effect on the exam performance of schools, and these effects are likely to be larger the longer the school has been receiving such funding.

Estimation of equation (2), however, will produce biased results arising from the endogeneity of covariates and the existence of unobserved heterogeneity (Mayston, 2007; De Fraja et al., 2006). The error term in equation (2) will include the effects of unmeasured features of both the school (e.g. teacher quality and school ethos) and the pupil (e.g. motivation and innate ability). These unobserved variables are likely to be correlated with observed covariates, and in particular with SPEC and EiC. There is also likely to be a correlation between family background and the school covariates. For instance, schools with a high proportion of pupils from 'favourable' family backgrounds (e.g. parents with a keen interest in their child's education) are likely to find it easier to recruit 'good' teachers, leading to better educational performance. If schools with good exam results attract 'good' teachers, some of the school covariates will be endogenous. Ignoring these problems may lead to serious bias in the estimated coefficients of the school quality variables, such as the pupil/teacher ratio (Mayston, 2007).

We attempt to mitigate this bias by including a range of time-varying covariates at both the school and district levels in addition to school and district dummies. Our estimating equation is as follows:

$$
Y_{s d t}=\alpha+\gamma \mathrm{COMP}_{s, t-n}+\eta \mathrm{SPEC}_{s, t-n}+\delta \mathrm{EiC}_{s, t-n}+\boldsymbol{X}_{s t} \boldsymbol{\beta}+\boldsymbol{Z}_{d t} \boldsymbol{\theta}+\boldsymbol{T}_{t} \tau+\alpha_{s}+\alpha_{d}+\varepsilon_{s d t},
$$

where $Y$ is the proportion of pupils achieving five or more $\mathrm{A}^{*}-\mathrm{C}$ grades in the GCSE exams (at age 16); COMP is the proportion of pupils achieving five or more $\mathrm{A}^{*}-\mathrm{C}$ grades in the GCSE exams (at age 16) in all other schools in the same district; SPEC is 1 if the school had a designated specialism (policy-on) and zero otherwise (policy-off); and, EiC is 1 if the school was in an EiC partnership (policy-on) and zero otherwise (policy-off).

The vectors $\boldsymbol{X}$ and $\boldsymbol{Z}$ are a set of time-varying school and district covariates respectively; and the vector $\boldsymbol{T}$ is a set of year dummies. The coefficients $\alpha_{s}$ and $\alpha_{d}$ are school and district fixed effects, which will capture the impact of unobserved, time-invariant school and district-level factors. The inclusion of school and district dummies should help in mitigating the potential bias on the estimated policy effects. The error term $\varepsilon$ is assumed to be normally distributed.

The vector $\boldsymbol{X}$ includes the following time-varying school-level variables: the pupil/teacher ratio, the number of pupils on the school roll, the proportion of pupils eligible for free school meals, the proportion with special needs and the proportion with English as their second language (see Table 1). The district-level variables include the proportion of pupils eligible for free school meals in other schools in the same district, the pupil/teacher ratio and the change in pupil numbers. These districtlevel variables are included to capture any shocks likely to impact on all schools within a district. We note that there may be a problem arising from the endogeneity of the time-varying school-level controls, such as the pupil/teacher ratio and the number 
of pupils in a school, which might be expected to increase over time in schools that perform well compared with their competitor schools. This could give rise to bias in the estimated policy effects but it seems unlikely that the bias, if it exists, will be serious as school size does not normally change rapidly in the short to medium term owing to capacity constraints in schools with a consistently good exam performance.

A further issue concerns the timing of the policy impacts. It seems likely that schools will react fairly quickly to increased competition from other schools in the same district as information about exam performance is readily available soon after the end of the school year. The impact of the specialist schools initiative and the EiC programme, however, is likely to be somewhat longer as their effect on exam results is likely to occur more gradually over time. Longer time lags may therefore be appropriate for these two policy variables.

The model can be modified in two ways to provide more information about the potential policy effects. First, as the EiC programme was introduced in three stages (in Phases 1, 2 and 3 in 1999, 2000 and 2001, respectively), it is possible to estimate the impact of each phase separately. Secondly, the effect of the specialist schools initiative on exam results can be estimated for 10 distinct specialist subject areas (see Table 2).

\section{Results}

This section reports the estimated impact of the education reforms on exam performance. ${ }^{13}$ We first estimate the individual impact of the three policy reforms. This is followed by estimates of their distributional impacts. We do this by sub-dividing schools into groups according to the proportion eligible for free school meals, the proportion from ethnic minorities and the gender of a school's pupils. Finally, we investigate whether the reforms have had differential effects according to school choice (measured by the number of schools in each district) and also according to market concentration (as measured by the concentration of pupils in schools within each district).

\section{The effect of the education reforms on exam performance}

To investigate the overall impact of the education reforms, we begin by regressing school exam performance on a set of year dummies in Model 1 (Table 3). This shows that the mean exam performance of all schools increased by 18 percentage points between 1994 and 2006. This serves as a benchmark for estimating the impact of the full range of variables specified in the previous section [see equation (3)]. Models 2 and 3 differ only insofar as Model 2 uses the Herfindahl index as the measure of competitiveness, whereas Model 3 uses the lagged exam performance of other schools

\footnotetext{
${ }^{13}$ The results reported here are based on an unbalanced panel as data are not available for the entire time period for a minority of schools. We note, however, that the results change very little when we use a balanced panel of 2,645 schools over the period 1992-2006.
} 
TABLE 3

Estimated regressions

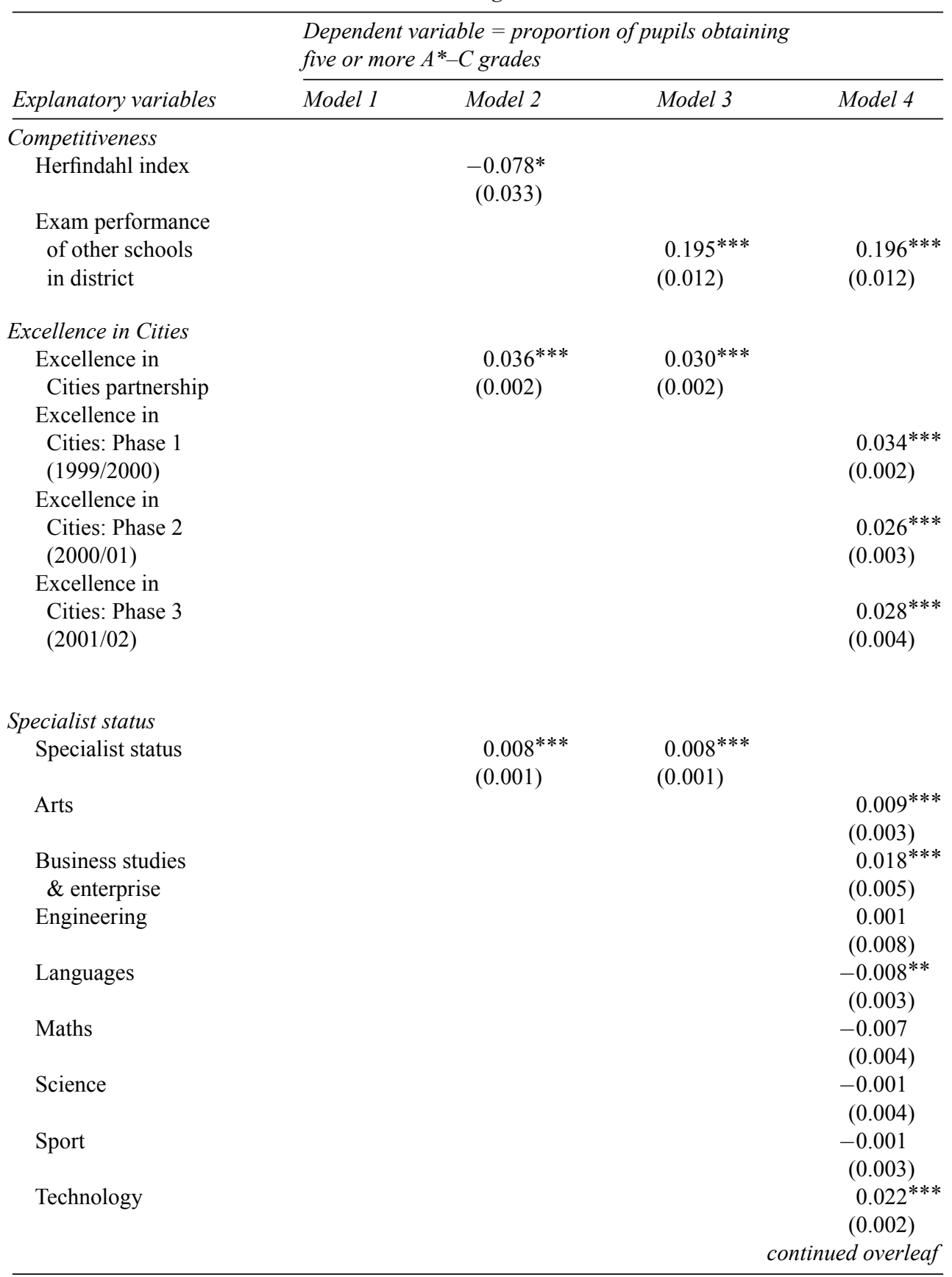


TABLE 3

(continued)

\begin{tabular}{|c|c|c|c|c|}
\hline \multirow[b]{2}{*}{ Explanatory variables } & \multicolumn{4}{|c|}{$\begin{array}{l}\text { Dependent variable }=\text { proportion of pupils obtaining } \\
\text { five or more } A^{*}-C \text { grades }\end{array}$} \\
\hline & Model 1 & Model 2 & Model 3 & Model 4 \\
\hline Humanities & & & & $\begin{array}{r}-0.012 \\
(0.015)\end{array}$ \\
\hline Music & & & & $\begin{array}{c}-0.033 \\
(0.027)\end{array}$ \\
\hline \multicolumn{5}{|l|}{ School variables } \\
\hline Pupil/teacher ratio & & $\begin{array}{c}-0.001^{*} \\
(0.000)\end{array}$ & $\begin{array}{l}-0.001^{* *} \\
(0.000)\end{array}$ & $\begin{array}{l}-0.001^{* *} \\
(0.000)\end{array}$ \\
\hline Part-time/full-time teachers & & $\begin{array}{c}0.001 \\
(0.005)\end{array}$ & $\begin{array}{l}0.002 \\
(0.004)\end{array}$ & $\begin{array}{c}0.002 \\
(0.004)\end{array}$ \\
\hline Pupils & & $\begin{array}{l}0.009^{* * *} \\
(0.001)\end{array}$ & $\begin{array}{l}0.009^{* * *} \\
(0.001)\end{array}$ & $\begin{array}{l}0.009^{* * *} \\
(0.001)\end{array}$ \\
\hline Pupils squared & & $\begin{array}{c}0.000 \\
(0.000)\end{array}$ & $\begin{array}{c}0.000 \\
(0.000)\end{array}$ & $\begin{array}{c}0.000 \\
(0.000)\end{array}$ \\
\hline $\begin{array}{l}\text { Proportion of pupils } \\
\text { eligible for free } \\
\text { school meals }\end{array}$ & & $\begin{array}{l}-0.276^{* * *} \\
(0.011)\end{array}$ & $\begin{array}{l}-0.272^{* * *} \\
(0.011)\end{array}$ & $\begin{array}{l}-0.268^{* * *} \\
(0.011)\end{array}$ \\
\hline $\begin{array}{l}\text { Proportion of pupils } \\
\text { with special } \\
\text { educational needs }\end{array}$ & & $\begin{array}{l}-0.110^{* * *} \\
(0.032)\end{array}$ & $\begin{array}{l}-0.127^{* * *} \\
(0.032)\end{array}$ & $\begin{array}{l}-0.125^{* * *} \\
(0.032)\end{array}$ \\
\hline $\begin{array}{l}\text { Proportion of pupils } \\
\text { with English as } \\
\text { second language }\end{array}$ & & $\begin{array}{c}0.074 \\
(0.075)\end{array}$ & $\begin{array}{c}0.021 \\
(0.075)\end{array}$ & $\begin{array}{c}0.031 \\
(0.075)\end{array}$ \\
\hline District variables & & & & \\
\hline $\begin{array}{l}\text { Proportion of pupils } \\
\text { eligible for free school } \\
\text { meals in other schools } \\
\text { in district }\end{array}$ & & $\begin{array}{l}-0.483^{* * *} \\
(0.049)\end{array}$ & $\begin{array}{l}-0.373^{* * *} \\
(0.049)\end{array}$ & $\begin{array}{l}-0.367^{* * *} \\
(0.049)\end{array}$ \\
\hline Change in number of pupils in district & & $\begin{array}{c}0.000 \\
(0.000)\end{array}$ & $\begin{array}{c}0.000 \\
(0.000)\end{array}$ & $\begin{array}{c}0.000 \\
(0.000)\end{array}$ \\
\hline Pupil/teacher ratio in district & & $\begin{array}{c}0.000 \\
(0.000)\end{array}$ & $\begin{array}{c}0.000 \\
(0.000)\end{array}$ & $\begin{array}{c}0.000 \\
(0.000)\end{array}$ \\
\hline 1995 & $\begin{array}{c}0.007 \\
(0.005)\end{array}$ & $\begin{array}{l}0.006^{* * *} \\
(0.002)\end{array}$ & $\begin{array}{c}0.002 \\
(0.002)\end{array}$ & $\begin{array}{c}0.002 \\
(0.002)\end{array}$ \\
\hline 1996 & $\begin{array}{l}0.021^{* * *} \\
(0.005)\end{array}$ & $\begin{array}{l}0.021^{* * *} \\
(0.002)\end{array}$ & $\begin{array}{l}0.015^{* * *} \\
(0.002)\end{array}$ & $\begin{array}{c}0.015 \\
(0.002)\end{array}$ \\
\hline 1997 & $\begin{array}{l}0.026^{* * *} \\
(0.005)\end{array}$ & $\begin{array}{l}0.024^{* * *} \\
(0.002)\end{array}$ & $\begin{array}{l}0.016^{* * *} \\
(0.002)\end{array}$ & $\begin{array}{l}0.015^{* * *} \\
(0.002)\end{array}$ \\
\hline 1998 & $\begin{array}{l}0.038^{* * * *} \\
(0.005)\end{array}$ & $\begin{array}{l}0.033^{* * *} \\
(0.002)\end{array}$ & $\begin{array}{l}0.023^{* * *} \\
(0.002)\end{array}$ & $\begin{array}{l}0.023^{* * *} \\
(0.002)\end{array}$ \\
\hline
\end{tabular}


TABLE 3

(continued)

\begin{tabular}{|c|c|c|c|c|}
\hline \multirow[b]{2}{*}{ Explanatory variables } & \multicolumn{4}{|c|}{$\begin{array}{l}\text { Dependent variable }=\text { proportion of pupils obtaining } \\
\text { five or more } A^{*}-C \text { grades }\end{array}$} \\
\hline & Model 1 & Model 2 & Model 3 & Model 4 \\
\hline \multirow[t]{2}{*}{1999} & $0.058^{* * *}$ & $0.049^{* * *}$ & $0.037^{* * *}$ & $0.036^{* * *}$ \\
\hline & $(0.005)$ & $(0.002)$ & $(0.002)$ & $(0.002)$ \\
\hline \multirow[t]{2}{*}{2000} & $0.070^{* * *}$ & $0.055^{* * *}$ & $0.039^{* * *}$ & $0.039^{* * *}$ \\
\hline & $(0.005)$ & $(0.002)$ & $(0.002)$ & $(0.002)$ \\
\hline \multirow[t]{2}{*}{2001} & $0.083^{* * *}$ & $0.063^{* * *}$ & $0.045^{* * *}$ & $0.044^{* * *}$ \\
\hline & $(0.005)$ & $(0.002)$ & $(0.002)$ & $(0.002)$ \\
\hline \multirow[t]{2}{*}{2002} & $0.100^{* * *}$ & $0.070^{* * *}$ & $0.050^{* * *}$ & $0.049^{* * *}$ \\
\hline & $(0.005)$ & $(0.002)$ & $(0.002)$ & $(0.002)$ \\
\hline \multirow[t]{2}{*}{2003} & $0.117^{* * *}$ & $0.080 * * *$ & $0.058 * * *$ & $0.057 * * *$ \\
\hline & $(0.005)$ & $(0.002)$ & $(0.002)$ & $(0.002)$ \\
\hline \multirow[t]{2}{*}{2004} & $0.129^{* * *}$ & $0.088^{* * *}$ & $0.063^{* * *}$ & $0.063^{* * *}$ \\
\hline & $(0.005)$ & $(0.002)$ & $(0.002)$ & $(0.002)$ \\
\hline \multirow[t]{2}{*}{2005} & $0.157^{* * *}$ & $0.115^{* * *}$ & $0.088^{* * *}$ & 0.088 \\
\hline & $(0.005)$ & $(0.002)$ & $(0.002)$ & $(0.003)$ \\
\hline \multirow[t]{2}{*}{2006} & $0.184^{* * *}$ & $0.124^{* * *}$ & $0.094^{* * *}$ & $0.095^{* * *}$ \\
\hline & $(0.005)$ & $(0.002)$ & $(0.003)$ & $(0.003)$ \\
\hline \multirow[t]{2}{*}{ Constant } & $0.399 * * *$ & $0.964^{* * *}$ & $0.463 * * *$ & $0.459 * * *$ \\
\hline & $(0.004)$ & $(0.096)$ & $(0.026)$ & $(0.026$ \\
\hline School fixed effects & No & Yes & Yes & Yes \\
\hline District fixed effects & No & Yes & Yes & Yes \\
\hline$R^{2}$ & 0.07 & 0.91 & 0.91 & 0.91 \\
\hline$n$ & 40,320 & 39,403 & 39,403 & 39,403 \\
\hline
\end{tabular}

Notes: ( ), standard errors. ${ }^{*}, * *$ and $* * *$ indicate significant at $5 \%, 1 \%$ and $0.1 \%$, respectively. The two measures of competitiveness (the Herfindahl index and the exam performance of other schools in the same district) are lagged 1 year in all regressions. The two policy variables (the Excellence in Cities programme and the specialist schools initiative) are lagged 2 years in all regressions. The means and standard deviations of the controls are provided in the Appendix.

in the same district. Finally, Model 4 estimates the impact of each of the three phases of the EiC programme and for each of the 10 types of school specialism.

We are not specifically interested in the variables used as controls but note that several are statistically significant in Models 2-4. These include the proportion of pupils eligible for free school meals (both within the school and within the local authority district), the pupil/teacher ratio, school size and the proportion of pupils with special needs. The pupil/teacher ratio, the proportion of pupils eligible for free school meals and the proportion of special needs pupils are negatively related to exam performance, as expected. As in previous studies (Bradley and Taylor, 1998), school size is found to be positively related to exam performance. ${ }^{14}$

\footnotetext{
${ }^{14}$ We note that excluding the time-varying school-level controls has very little effect on the estimated policy impacts.
} 
In view of the likelihood that education policies have a lagged impact on a school's exam performance, we have experimented with policy lags of different lengths. As argued earlier, a 1-year lag is probably appropriate for the competition variable as schools need to react quickly to improvements achieved by competing schools in the same catchment area if they are to maintain their competitiveness. ${ }^{15}$ The impact lag on exam performance of the EiC and specialist schools policies, however, is likely to be somewhat longer. The estimated coefficient on the EiC policy variable, for example, is 0.20 with a zero time lag compared with 0.30 when we use a 2-year lag (the difference is highly statistically significant). As using further lags (up to 4 years) does not result in a statistically significant change in the estimated coefficient, we use a 2-year lag in all of the regressions reported here. ${ }^{16}$ A 2-year time lag is also used for the specialist schools variable, although there is little difference between the estimated coefficients using different lags in this case. ${ }^{17}$

Using the Herfindahl index (lagged 1 year) to measure competitiveness, we find a negative relationship as expected (see Model 2), but the estimated coefficient indicates a very small impact as the Herfindahl is very stable over the study period (even within districts). This means that it does not (in this case) accurately track the extent to which schools are competing with each other for pupils following the introduction of the quasi-market. As argued in section III, the lagged exam performance of other schools in the same district is likely to provide a more sensitive measure of competitiveness than the Herfindahl in a time-series analysis. Schools that do not keep pace with other schools in the same catchment area are likely to lose market share.

Replacing the Herfindahl with the lagged exam performance of other schools in the same district as the measure of competitiveness facing each school (see Model 3 ), we find that a one percentage point increase in the exam performance of other schools in the same district is associated with a 0.2 percentage point increase in the school's own exam performance. This suggests that competition between schools was associated with an improvement of 4 percentage points in the overall exam score during 1994-2006. ${ }^{18}$

The estimated coefficient on the EiC variable indicates that the EiC programme has been associated with a three percentage point improvement in the exam performance of those schools participating in the programme. The estimated impact of the specialist

\footnotetext{
${ }^{15}$ We note that the estimated coefficient on the competition variable falls from $0.20(\mathrm{SE}=0.012)$ to 0.13 $(\mathrm{SE}=0.012)$ when it is lagged by 2 years rather than 1 year (not reported).

${ }^{16} \mathrm{~A}$ disadvantage of extending the lag is that the sample size falls by around 3,000 schools for each extra 1-year lag.

${ }^{17}$ We also note that the estimated coefficient on the specialist schools variable is not only insensitive to the length of the lag but also remains stable even when this variable is used as a leading indicator of the policy impact. This is not the case for the estimated coefficient on the EiC policy variable, however, which falls sharply when this variable is used as a leading indicator of the policy impact. The fact that the two policy variables remain statistically significant, however, suggests that they may capture some other (unspecified but coterminous) factors which have had an impact on exam performance.

${ }^{18}$ This estimate is obtained by multiplying the estimated coefficient on the lagged exam performance of all other schools in the district $(0.20)$ by the change in the exam performance of all other schools in the district over the period 1993-2006 (20 percentage points).
} 
schools initiative, however, appears to have been quite small, with the acquisition of specialist status being associated with an improvement in exam performance of just below one percentage point. Adding the impact of the three education reforms together, we estimate that they improved the overall exam performance by nearly six percentage points during 1994-2006. Model 3 therefore indicates that around onethird of the improvement in exam results during 1994-2006 can be directly attributed to the three major education reforms. The regression results also indicate that the trend growth in average school size of around 200 pupils per school during the period was associated with a two percentage point improvement in exam results. ${ }^{19}$

The impact of the specialist schools initiative and the EiC programme is investigated in more detail in Model 4. The EiC programme was phased in over 3 years and hence those in the first phase have received extra funding for longer and are expected to have experienced the greatest improvement in performance. On average, schools included in Phase 1 (in the 1999/2000 school year) witnessed a 3.4 percentage point improvement in exam performance, whereas those schools in Phases 2 and 3 exhibit a significantly smaller improvement ( 2.6 and 2.8 percentage points, respectively). ${ }^{20}$

The specialist schools initiative can similarly be split into different specialisms to estimate the impact for each type of specialist school. When this is done, we find that the specialist schools initiative is significantly positively related to exam performance for only three of the ten specialisms (which accounted for $40 \%$ of all specialist schools in 2006). The impact on the exam performance of schools specializing in arts, business studies and technology is estimated to be $0.9,1.8$ and 2.2 percentage points, respectively.

As the impact of education policies may change over time, it is useful to estimate the policy effects over different time periods. Table 4 shows the estimated coefficients over consecutively longer time periods running from 1994-2000 through to 1994-2006. The estimated impact of competition policy on exam results is shown to increase steadily over time as the quasi-market evolved, as we would expect. A similar result is obtained for the EiC programme, which is also estimated to have had a stronger impact over time for each of the three phases of the policy. This is consistent with the view that increasing school resources to raise the performance of pupils from deprived family backgrounds is likely to take time to change behaviour and attitudes towards schooling, thereby improving educational outcomes.

In contrast, the specialist schools initiative appears to have become less effective over time, presumably because of the selective nature of this policy. In the earlier years of the programme, schools had to be seen to be performing well to be awarded

\footnotetext{
${ }^{19} \mathrm{~A}$ potential problem arises in the interpretation of the estimated policy effects on the $\mathrm{EiC}$ and specialist schools variables as a minority of schools acquired EiC status and specialist school status simultaneously. Omitting those schools with coterminous policies (about $20 \%$ of the total by 2006), the estimated policy effect falls from 0.30 to 0.20 on the EiC variable and from 0.008 to 0.004 on the specialist schools variable. (Both new estimates are still highly statistically significant.) In addition, the estimated policy effects for each of the three policies are unaffected by the omission of each policy variable in turn.

${ }^{20}$ Machin et al. (2007) find that the impact of each phase of the EiC policy on Key Stage 3 results in maths gradually builds up over time.
} 
TABLE 4

Estimated policy impacts over time

\begin{tabular}{llllll}
\hline Period & $\begin{array}{l}\text { Competition } \\
\text { between schools }\end{array}$ & $\begin{array}{l}\text { Specialist schools } \\
\text { programme }\end{array}$ & $\begin{array}{l}\text { EiC Phase 1: } \\
1999 / 2000\end{array}$ & $\begin{array}{l}\text { EiC Phase 2: } \\
2000 / 01\end{array}$ & $\begin{array}{l}\text { EiC Phase 3: } \\
2001 / 02\end{array}$ \\
\hline $1994-2002$ & $0.136^{* * *}$ & $0.015^{* * *}$ & $0.011^{* * *}$ & & \\
& $(0.014)$ & $(0.002)$ & $(0.003)$ & & \\
$1994-2003$ & $0.146^{* * *}$ & $0.018^{* * *}$ & $0.018^{* * *}$ & $0.016^{* * *}$ & \\
& $(0.013)$ & $(0.002)$ & $(0.002)$ & $(0.004)$ & \\
$1994-2004$ & $0.158^{* * *}$ & $0.014^{* * *}$ & $0.025^{* * *}$ & $0.016^{* * *}$ & $0.011^{*}$ \\
& $(0.013)$ & $(0.002)$ & $(0.002)$ & $(0.003)$ & $(0.005)$ \\
$1994-2005$ & $0.175^{* * *}$ & $0.011^{* * *}$ & $0.032^{* * *}$ & $0.022^{* * *}$ & $0.021^{* * *}$ \\
& $(0.012)$ & $(0.001)$ & $(0.002)$ & $(0.003)$ & $(0.004)$ \\
$1994-2006$ & $0.234^{* * *}$ & $0.008^{* * *}$ & $0.034^{* * *}$ & $0.026^{* * *}$ & $0.028^{* * *}$ \\
& $(0.012)$ & $(0.001)$ & $(0.002)$ & $(0.003)$ & $(0.004)$ \\
\hline
\end{tabular}

Notes: ( ), standard errors. $*, * * *$ indicate significant at $5 \%$ and $0.1 \%$, respectively. The coefficients reported in this table are obtained from regressions which include all of the controls used in estimating Models 2-4 in Table 3. The year dummies and the school and district fixed effects are also included.

EiC, Excellence in Cities.

specialist status, as poorly performing schools would be less likely to find sponsors to provide matched funding from the private sector. ${ }^{21}$ As the scheme expanded to cover the majority of schools (see Table 1), the effectiveness of the policy is estimated to have declined. This decline in the estimated impact of the specialist schools initiative may therefore be a consequence not of a causal effect of the policy but of a change in the characteristics of schools gaining specialist status. Schools gaining specialist status before 2001, for example, had a better average exam performance than nonspecialist schools. After 2004, the reverse was the case. If schools with a poor exam performance were less likely to gain from acquiring specialist status than schools with a good exam performance, this compositional change could explain (at least in part) the decline in the estimated impact of the policy. The inclusion of variables such as the proportion of pupils eligible for free school meals to control for differences in the pupil composition of schools should, however, help in mitigating the influence of the compositional change on the estimated impact of the specialist schools initiative. At the worst, it could be argued that the specialist schools policy may have been effective only for high performing schools. ${ }^{22}$

\section{The distributional effects of the education reforms}

In this section, we investigate whether the education reforms have benefited some groups of pupils more than others. Specifically, we test for the effect of the reforms according to family poverty, ethnicity and gender of admissions. As the analysis is conducted at the school level and not at the pupil level, the results reported here

${ }^{21}$ The matched funding requirement has been relaxed in recent years.

${ }^{22} \mathrm{We}$ thank one of the referees for suggesting this explanation to us. 
should be taken as preliminary estimates of the distributional consequences of the reforms. Further work at pupil level is required to obtain more robust estimates.

The distributional consequences of the three policies are estimated by dividing schools into quintiles according to a specific characteristic, such as the proportion of pupils eligible for free school meals (as in Table 5). We find that none of the three policies had any impact on the exam performance of schools with a low proportion of pupils from poor families (relative to non-treated schools in the same quintile). There is some evidence, however, that the impact of the specialist schools initiative has been greater for schools with a higher proportion of pupils from poor families than for schools with lower proportions.

When schools are grouped according to the proportion of ethnic minority pupils, we find that the impact of all three policy reforms is estimated to be highest for schools with a high proportion of pupils from ethnic minorities (relative to non-treated schools in the same group). The estimated impact of the EiC programme, for example, is 2 percentage points for schools with less than $10 \%$ ethnic minority pupils compared with 3.6 percentage points for schools with more than $50 \%$ of its pupils from an ethnic minority (see Table 6). This result is not surprising as the EiC programme was aimed specifically at inner city schools with a high proportion of pupils from low-income families.

The final distributional aspect of the benefits of the education reforms relates to gender differences in exam performance. ${ }^{23}$ The model is estimated for three different

TABLE 5

Estimated policy effects by proportion of pupils eligible for free school meals

\begin{tabular}{llcc}
\hline $\begin{array}{l}\text { Average \% eligible } \\
\text { for free school meals }\end{array}$ & $\begin{array}{l}\text { Competition } \\
\text { between } \\
\text { (1992-2006): by quintile }\end{array}$ & $\begin{array}{l}\text { Excellence } \\
\text { in Cities } \\
\text { partnership }\end{array}$ & $\begin{array}{l}\text { Specialist } \\
\text { schools } \\
\text { programme }\end{array}$ \\
\hline Lowest \% eligible for free meals ('rich kids') & -0.010 & 0.002 & 0.002 \\
& $(0.022)$ & $(0.006)$ & $(0.002)$ \\
Second quintile & $0.141^{* * *}$ & $0.017^{* *}$ & $0.009^{* * *}$ \\
& $(0.024)$ & $(0.006)$ & $(0.003)$ \\
Third quintile & $0.234^{* * *}$ & $0.011^{* *}$ & $0.010^{* * *}$ \\
Fourth quintile & $(0.024)$ & $(0.004)$ & $(0.003)$ \\
& $0.216^{* * *}$ & $0.020^{* * *}$ & $0.018^{* * *}$ \\
Highest \% eligible for free meals ('poor kids') & $(0.028)$ & $(0.003)$ & $(0.003)$ \\
& $0.226^{* * *}$ & $0.011^{* *}$ & $0.021^{* * *}$ \\
\hline
\end{tabular}

Notes: ( ), standard errors. ${ }^{* *}$ and $* * *$ indicate significant at $1 \%$ and $0.1 \%$, respectively. The coefficients reported in this table are obtained from regressions which include all of the controls used in estimating Models 2-4 in Table 3. The year dummies and the school and district fixed effects are also included.

\footnotetext{
${ }^{23}$ The factors underlying the evolution of the gender gap in exam results are investigated by Andrews et al. (2006), who argue that part of the explanation for the trend improvement in girls' exam results relative to boys was the switch to an examination system based more heavily on coursework from the late 1980s. There is evidence that girls prefer coursework and this could account for the increase in the gender gap as well as an improvement in the results overall (Machin and McNally, 2005). See also Casson and Kingdom (2007) and Kingdom and Casson (2007).
} 
TABLE 6

Estimated policy effects by proportion of pupils in ethnic minority

\begin{tabular}{llccc}
\hline $\begin{array}{l}\text { Average \% of pupils } \\
\text { in ethnic minority } \\
\text { (1992-2006): by quintile }\end{array}$ & $\begin{array}{l}\text { Number of } \\
\text { schools } \\
(2006)\end{array}$ & $\begin{array}{l}\text { Competition } \\
\text { between } \\
\text { schools }\end{array}$ & $\begin{array}{l}\text { Excellence } \\
\text { in Cities } \\
\text { partnership }\end{array}$ & $\begin{array}{l}\text { Specialist } \\
\text { schools } \\
\text { programme }\end{array}$ \\
\hline Below 10\% ethnic minority pupils & 2,197 & $0.166^{* * *}$ & $0.020^{* * *}$ & $0.010^{* * *}$ \\
& & $(0.013)$ & $(0.002)$ & $(0.001)$ \\
$10-50 \%$ ethnic minority pupils & 637 & $0.157^{* * *}$ & $0.029^{* * *}$ & 0.001 \\
& & $(0.030)$ & $(0.003)$ & $(0.003)$ \\
Over 50\% ethnic minority pupils & 283 & $0.228^{* * *}$ & $0.036^{* * *}$ & $0.016^{* * *}$ \\
& & $(0.042)$ & $(0.005)$ & $(0.005)$ \\
\hline
\end{tabular}

Notes: ( ), standard errors. $* * *$ indicates significant at $0.1 \%$. The coefficients reported in this table are obtained from regressions which include all of the controls used in estimating Models 2-4 in Table 3 . The year dummies and the school and district fixed effects are also included.

TABLE 7

Estimated policy effects by gender of admissions

\begin{tabular}{lcccc}
\hline $\begin{array}{l}\text { Gender of } \\
\text { pupils }\end{array}$ & $\begin{array}{l}\text { Number of } \\
\text { schools }\end{array}$ & $\begin{array}{l}\text { Competition } \\
\text { between } \\
\text { schools }\end{array}$ & $\begin{array}{l}\text { Excellence } \\
\text { in Cities } \\
\text { partnership }\end{array}$ & $\begin{array}{l}\text { Specialist } \\
\text { schools } \\
\text { programme }\end{array}$ \\
\hline Boys only schools & 180 & $0.161^{* * *}$ & $0.046^{* * *}$ & -0.008 \\
& & $(0.051)$ & $(0.007)$ & $(0.006)$ \\
Girls only schools & 227 & $0.093^{*}$ & $0.062^{* * *}$ & 0.001 \\
& & $(0.044)$ & $(0.006)$ & $(0.004)$ \\
Co-educational schools & 2,710 & $0.208^{* * *}$ & $0.027^{* * *}$ & $0.009^{* * *}$ \\
& & $(0.012)$ & $(0.002)$ & $(0.001)$ \\
\hline
\end{tabular}

Notes: ( ), standard errors. $*$ and $* * *$ indicate significant at $5 \%$ and $0.1 \%$, respectively. The coefficients reported in this table are obtained from regressions which include all of the controls used in estimating Models 2-4 in Table 3. The year dummies and the school and district fixed effects are also included.

types of schools according to whether they are boys-only, girls-only or co-educational schools (see Table 7). The most interesting, and perhaps most surprising, result is that single-sex schools benefited more from the EiC programme than did co-educational schools (relative to non-treated schools in the same admissions category). This programme is estimated to have boosted exam performance by 4.6 and 6.2 percentage points in boys-only and girls-only schools, respectively compared with only 2.7 percentage points in co-educational schools. Neither boys-only nor girls-only schools, however, are estimated to have benefited from the specialist schools initiative (relative to non-treated schools in the same admissions category). ${ }^{24}$

\footnotetext{
${ }^{24}$ The proportion of boys-only and girls-only schools in an EiC partnership was 31\% and 39\%, respectively. The gap in exam performance between non-EiC schools and EiC schools fell from 25.5 to 15.7 for boys-only schools, and from 21.9 to 12.7 for girls-only schools, between 2000 and 2006.
} 


\section{Spatial variations in the effect of the policy reforms}

The impact of the degree of competition and of parental choice on a school's attainment may be expected to vary between districts. Two measures are used here to capture these spatial disparities in competition and parental choice. The first is simply the number of schools in a district, which reflects the degree of choice available to parents. Dividing districts into categories according to the number of schools, we find that the estimated coefficient on the competition variable increases from 0.086 to 0.394 as we move from districts with less than 5 schools to districts with more than 15 schools (see Table 8). Moreover, the estimated coefficient increases at an increasing rate. This result therefore supports the view that competition has been most effective in those districts where parental choice is the greatest. ${ }^{25}$

The second measure of competition at the district level is the Herfindahl index, which is inversely related to the degree of concentration of pupils in a district's schools. Dividing districts into categories according to the degree of concentration of a district's pupils, we find that the estimated coefficient on the competition variable increases from 0.096 in the quintile of schools with the highest concentration of pupils to 0.398 for schools in the lowest. There is therefore strong evidence that the impact of competition on a school's exam performance is positively related to the degree of market concentration faced by schools within their catchment area.

TABLE 8

Estimated policy effects by number of schools in district

\begin{tabular}{|c|c|c|c|c|c|c|}
\hline $\begin{array}{l}\text { Number of } \\
\text { schools in } \\
\text { district (2006) }\end{array}$ & $\begin{array}{l}\text { Number of } \\
\text { schools } \\
\text { (2006) }\end{array}$ & $\begin{array}{l}\text { Number of } \\
\text { EiC partnership } \\
\text { schools (2006) }\end{array}$ & $\begin{array}{l}\text { Number of } \\
\text { specialist } \\
\text { schools (2006) }\end{array}$ & $\begin{array}{l}\text { Competition } \\
\text { between } \\
\text { schools }\end{array}$ & $\begin{array}{l}\text { EiC } \\
\text { partnership }\end{array}$ & $\begin{array}{l}\text { Specialist } \\
\text { schools } \\
\text { programme }\end{array}$ \\
\hline $1-4$ & 206 & 4 & 177 & $\begin{array}{l}0.086^{* * * *} \\
(0.028)\end{array}$ & - & $\begin{array}{c}-0.001 \\
(0.004)\end{array}$ \\
\hline $5-7$ & 827 & 6 & 696 & $\begin{array}{l}0.118^{* * *} \\
(0.020)\end{array}$ & - & $\begin{array}{c}0.004 \\
(0.002)\end{array}$ \\
\hline $8-10$ & 652 & 108 & 497 & $\begin{array}{l}0.159^{* * *} \\
(0.027)\end{array}$ & $\begin{array}{l}0.050^{* * *} \\
(0.004)\end{array}$ & $\begin{array}{c}0.005 \\
(0.003)\end{array}$ \\
\hline $11-15$ & 649 & 279 & 475 & $\begin{array}{l}0.256^{* * *} \\
(0.029)\end{array}$ & $\begin{array}{l}0.021^{* * *} \\
(0.003)\end{array}$ & $\begin{array}{l}0.015^{* *} \\
(0.003)\end{array}$ \\
\hline 16 and over & 719 & 460 & 549 & $\begin{array}{l}0.394^{* * *} \\
(0.035)\end{array}$ & $\begin{array}{l}0.017^{* * * *} \\
(0.003)\end{array}$ & $\begin{array}{l}0.009^{* *} \\
(0.003)\end{array}$ \\
\hline
\end{tabular}

Notes: ( ), standard errors. $* *$ and $* * *$ indicate significant at $1 \%$ and $0.1 \%$, respectively. There is no estimated coefficient for the Excellence in Cities (EiC) Partnership programme for districts with less than eight schools as there were too few districts to obtain meaningful results. The coefficients reported in this table are obtained from regressions which include all of the controls used in estimating Models 2-4 in Table 3 . The year dummies and the school and district fixed effects are also included.

\footnotetext{
${ }^{25} \mathrm{~A}$ similar result is obtained when the number of schools within a radius of $7 \mathrm{~km}$ of each school is used for dividing schools into groups instead of using the number of schools in the local authority district. The eastings and northings used to delineate the $7 \mathrm{~km}$ radius for each school, and hence the number of other secondary schools within this radius, were obtained from the Postzon package.
} 
TABLE 9

Estimated policy effects by degree of concentration of pupils in schools within districts

\begin{tabular}{lccc}
\hline $\begin{array}{l}\text { Herfindahl index } \\
\text { (average for 1992-2006 } \\
\text { by quintile) }\end{array}$ & $\begin{array}{l}\text { Competition } \\
\text { between } \\
\text { schools }\end{array}$ & $\begin{array}{l}\text { Excellence } \\
\text { in Cities } \\
\text { partnership }\end{array}$ & $\begin{array}{l}\text { Specialist } \\
\text { schools } \\
\text { programme }\end{array}$ \\
\hline Districts with lowest concentration of pupils & $0.398^{* * *}$ & $0.016^{* * *}$ & $0.007^{*}$ \\
& $(0.036)$ & $(0.003)$ & $(0.003)$ \\
Second quintile & $0.265^{* * *}$ & $0.020^{* * *}$ & $0.013^{* * *}$ \\
& $(0.031)$ & $(0.003)$ & $(0.003)$ \\
Third quintile & $0.206^{* * *}$ & $0.036^{* * *}$ & $0.008^{* *}$ \\
& $(0.029)$ & $(0.004)$ & $(0.003)$ \\
Fourth quintile & $0.094^{* * *}$ & $0.056^{* * *}$ & $0.010^{* * *}$ \\
& $(0.027)$ & $(0.008)$ & $(0.003)$ \\
Districts with highest concentration of pupils & $0.096^{* * *}$ & $0.034^{*}$ & 0.001 \\
& $(0.019)$ & $(0.017)$ & $(0.003)$ \\
\hline
\end{tabular}

Notes: ( ), standard errors. $*, * *$ and $* * *$ indicate significant at $5 \%, 1 \%$ and $0.1 \%$, respectively. The Herfindahl index is the sum over all schools in a district of $s_{i}^{2}$, where $s_{i}$ is each school's proportion of the district's pupils. The coefficients reported in this table are obtained from regressions which include all of the controls used in estimating Models 2-4 in Table 3. The year dummies and the school and district fixed effects are also included.

The impact of the EiC policy is also estimated to vary according to the degree of competition faced by schools. Its impact is estimated to be lowest in districts where competition is high (i.e. a low concentration of pupils in a district's schools) and is estimated to be high in districts where competition is low. This result may be because the EiC programme depends on cooperation between schools and cooperation may be easier to achieve in districts with only a small number of schools involved in the programme.

We therefore conclude, from the results in Tables 8 and 9, that competition works best where choice is greatest, and cooperation works best where there are fewer schools to coordinate in a partnership arrangement such as the EiC policy.

\section{Conclusion}

This article has investigated the impact on exam performance of three major education policies that have been introduced into England's secondary schools during the past two decades. Following the Education Reform Act (Department of Education and Science, 1988), a quasi-market was created in the early 1990s by providing schools with increased control over their own resources and by linking each school's funding more directly to its intake of pupils. On the other side of the equation, parental choice of school has been considerably increased. Moreover, schools were increasingly differentiated by the specialist schools initiative, which began in 1994 with the designation of technology colleges. In addition to expanding the choice set to 10 different specialisms in subsequent years (and more recently to a combination of any 
two specialisms), policy has become more heavily focused on schools in areas of severe deprivation through the EiC programme.

This article has attempted to estimate the effect of these three education policies on the exam performance of pupils at the end of compulsory education. Our main findings, which are based on a panel of all secondary schools in England (1992-2006), are as follows. First, our estimates suggest that between $20 \%$ and $25 \%$ of the overall improvement in exam performance over the period 1992-2006 can be attributed specifically to the quasi-market reforms. This policy had a far bigger impact, however, in areas where competition is likely to be more intense and where parental choice is likely to be greater. The impact of competition was found to be substantially greater, for example, in districts which had the most schools and in districts with the lowest concentration of pupils in just a few schools (as measured by the Herfindahl index).

Secondly, the impact of the specialist schools initiative on exam performance is estimated to have been modest, improving exam performance by less than one percentage point for specialist schools as a whole. Some specialisms, however, are estimated to have had a bigger impact on exam performance than others, with the largest effects being for schools specializing in technology ( 2.2 percentage points) and in business studies (1.8 percentage points). No discernible effect could be detected for the majority of specialist schools, however, suggesting that a large proportion of the specialist schools funding yielded no significant improvement in exam performance.

Thirdly, the EiC programme is estimated to have had some success, insofar as it is estimated to have accounted for a three percentage point improvement in GCSE results for participating schools during 2000-06 (when exam results in England improved by 11 percentage points overall). The overall effect on exam performance has been relatively small, however, as it has been mainly restricted to schools in deprived urban areas.

Although the education reforms are estimated to have had only a moderate impact on exam performance in aggregate, there is convincing evidence that the impacts that did occur have been distributionally beneficial. Our estimates suggest that increased competition had the greatest impact on exam performance in those schools with the most disadvantaged pupils. The same result was obtained for the specialist schools initiative, which also had its biggest impact in schools with the most disadvantaged pupils. Specifically, these two policies benefited those schools with the highest proportion of pupils from poor families and with the highest proportion of ethnic minority pupils. The schools benefiting most from the EiC programme were those with a high proportion of pupils from ethnic minorities. This result is not surprising as the aim of the EiC programme was to raise attainment in deprived urban areas. In fact, all three policies are estimated to have had a greater impact on schools with a high proportion of ethnic minority pupils.

The impact of the education reforms taken as a whole has therefore been moderate, with about one-third of the total improvement in exam performance being directly attributable to these three reforms. The question therefore arises as to what factors account for the improvement in secondary school exam results not accounted for 
by the reforms to education policy considered in this article. One possibility is that improvements to primary education have fed through into the secondary school sector as a result not only of specific programmes such as the literacy and numeracy hour (see Machin and McNally, 2008) but also the introduction of national tests at the end of primary schooling. Other possible explanations for the 'unexplained' improvement in exam results are that pupils and teachers have worked harder or that schools have been managed more efficiently. It may also be the case that exams have become easier or that assessment methods have become less stringent. In other words, there may have been grade inflation. These issues need to be investigated more fully using pupil-level data in future research.

Final Manuscript Received: July 2009

\section{References}

Andrews, M., Bradley, S., Stott, D. and Taylor, J. (2006). The Evolution and Determinants of the Educational Gender Gap, Working Paper, Department of Economics, Lancaster University.

Bearse, P., Glomm, G. and Ravikumar, B. (2000). 'On the political economy of means-tested education vouchers', European Economic Review, Vol. 44, pp. 904-915.

Blair J. P. and Staley, S. (1995). 'Quality competition and public schools; further evidence', Economics of Education Review, Vol. 14, pp. 193-208.

Borland, M. V. and Howsen, R. M. (1992). 'Student academic achievement and the degree of market concentration in education', Economics of Education Review, Vol. 11, pp. 31-39.

Bradley, S. and Taylor, J. (1998). 'The effect of school size on exam performance in secondary schools', Oxford Bulletin of Economics and Statistics, Vol. 60, pp. 291-324.

Bradley, S. and Taylor, J. (2002). 'The effect of the quasi-market on the efficiency-equity trade-off in the secondary school sector', Bulletin of Economic Research, Vol. 54, pp. 295-314.

Bradley, S. and Taylor, J. (2004). 'Ethnicity, educational attainment and the transition from school', The Manchester School, Vol. 72, pp. 317-346.

Bradley, S., Crouchley, R., Millington, J. and Taylor, J (2000). 'Testing for quasi-market forces in secondary education', Oxford Bulletin of Economics and Statistics, Vol. 62, pp. 357-390.

Bradley, S., Johnes, G. and Millington, J. (2001). 'School choice, competition and the efficiency of secondary schools in England', European Journal of Operational Research, Vol. 135, pp. 545-568.

Casson, R. and Kingdom, G. (2007). Tackling Low Educational Achievement, Joseph Rowntree Foundation, York.

Department of Education and Science (1988). Education Reform: The Government's Proposals for Schools, HMSO, London.

De Fraja, G. and Landeras, P. (2006). 'Could do better: the effectiveness of incentives and competition in schools', Journal of Public Economics, Vol. 90, pp. 189-213.

De Fraja, G., Oliveira, T. and Zanchi, L. (2005). 'Must try harder. Evaluating the role of effort in educational attainment', CEPR Discussion Papers 5048 CEPR, London.

Fernandez, R. and Rogerson, R. (1999). Equity and Resources: An Analysis of Education Finance Systems, NBER Working Paper 7111, Cambridge, MA.

Fiske, E. B. and Ladd, H. (2000). When Schools Compete: A Cautionary Tale, Brookings Institute, Washington, DC.

Friedman, M. (1962). Capitalism and Freedom, University of Chicago Press, Chicago.

Gibbons, S., Machin, S. and Silva, O. (2006). Choice, Competition and Pupil Achievement, Discussion Paper, Centre for the Economics of Education, London School of Economics. 
Glennerster, H. (1991). ‘Quasi-markets for education?’ Economic Journal, Vol. 101, pp. 1268-1276.

Gorard, S. (2002). 'Let's keep it simple: the multilevel model debate', Research Intelligence, Vol. 81, p. 24.

Hanushek, E. A. (1979). 'Conceptual and empirical issues in the estimation of educational production functions', Journal of Human Resources, Vol. 14, pp. 351-388.

Hanushek, E. A. (1986). 'The economics of schooling: production and efficiency in public schools', Journal of Economic Literature, Vol. 24, pp. 1141-1177.

Hanushek, E. A. (2003). 'The failure of input-based schooling policies', Economic Journal, Vol. 113, pp. F64-F98.

House of Commons (2003). Secondary Education: Diversity of Provision, Education and Skills Committee, HC94.

Hoxby, C. M. (1996). 'Are efficiency and equity in school finance substitutes or complements?' Journal of Economic Perspectives, Vol. 10, pp. 51-72.

Hoxby, C. M. (1998). The Effects of Class Size and Composition on Student Achievement: New Evidence from Natural Population Variation, Working Paper 6869, NBER, Cambridge, MA.

Hoxby, C. M. (1999). The Productivity of Schools and Other Local Public Good Producers, NBER Working Paper 6911, Cambridge, MA.

Jesson, D. (2002). 'Response to the article by Schagen and Goldstein', Research Intelligence, Vol. 80, p. 16.

Jesson, D. and Crossley, D. (2004). Educational Outcomes and Value Added by Specialist Schools, Specialist Schools Trust (http://www.specialistschoolstrust.org.uk, last accessed May 2006).

Kendall, L., O’Donnell, L., Golden, S., Ridley, K., Machin, S., Rutt, S., McNally, S., Schagen, I., Meghir, C., Stoney, S., Morris, M., West, A. and Noden, P. (2005). Excellence in Cities: The National Evaluation of a Policy to Raise Standards in Urban Schools 2000-2003, Research Report RR675a, Department for Education and Skills, London.

Kingdom, G. and Casson, R. (2007). Understanding Low Achievement in English Schools, Centre for Analysis of Social Exclusion, CASE/118, London School of Economics.

Krueger, A. B. (2003). 'Economic considerations of class size', Economic Journal, Vol. 113, pp. F34F63.

Le Grand, J. (1991). 'Quasi-markets and social policy', Economic Journal, Vol. 101, pp. 1256-1267.

Le Grand, J. (1993). Quasi-Markets and Social Policy. Macmillan, London.

Levacic, R. and Hardman, J. (1998). 'Competing for resources: the impact of social disadvantage and other factors on English secondary schools' financial performance', Oxford Review of Education, Vol. 24, pp. 303-328.

Levacic, R. and Jenkins, A. (2004). Evaluating the Effectiveness of Specialist Schools, Centre for the Economics of Education, London School of Economics, London.

Levin, H. M. (1991a). 'The economics of educational choice', Economics of Education Review, Vol. 10, pp. $137-158$.

Levin, H. M. (1991b). 'Views on the economics of educational choice: a reply to West', Economics of Education Review, Vol. 10, pp. 171-175.

Machin, S. and McNally, S. (2005). 'Gender and student achievement in English schools', Oxford Review of Economic Policy, Vol. 21, 357-372.

Machin, S. and McNally, S. (2008). 'The literacy hour', Journal of Public Economics, Vol. 92, pp. 1441-1462.

Machin, S., McNally, S. and Meghir, C. (2004). 'Improving pupil performance in English secondary schools: Excellence in Cities', Journal of the European Economic Association, Vol. 2, pp. 396-405.

Machin, S., McNally, S. and Meghir, C. (2007). Resources and Standards in Urban Schools, Centre for the Economics of Education, London School of Economics.

Marlow, M. L. (1997). 'Public education supply and student performance', Applied Economics, Vol. 29, pp. 617-626. 
Marlow, M. L. (2000). 'Spending, school structure, and public education quality: evidence from California', Economics of Education Review, Vol. 19, pp. 89-106.

Mayston, D. (2007). 'Competition and resource effectiveness', The Manchester School, Vol. 75, pp. 47 64.

Nechyba, T. J. (2000). 'Mobility, targeting and private-school vouchers', American Economic Review, Vol. 90, pp. 130-146.

Noden, P. and Schagen, I. (2006). 'The specialist schools programme: golden goose or conjuring trick?' Oxford Review of Education, Vol. 32, pp. 431-448.

Office for Standards in Education (OFSTED) (2005). Specialist Schools: A Second Evaluation, Ref. HMI 2362, OFSTED, London.

Schagen, I. and Goldstein, H. (2002). 'Do specialist schools add value? Some methodological problems', Research Intelligence, Vol. 80, pp. 12-15.

Taylor, J. (2007). 'Estimating the impact of the specialist schools programme on secondary school examination results in England', Oxford Bulletin of Economics and Statistics, Vol. 69, pp. 445-471.

Zanzig, B. R. (1997). 'Measuring the impact of competition in local government education markets on the cognitive achievement of students', Economics of Education Review, Vol. 16, pp. 431-441.

\section{Appendix}

TABLE A1

Descriptive statistics

\begin{tabular}{lrrr}
\hline Variable & $N$ & Mean & SD \\
\hline $\begin{array}{l}\text { Proportion of pupils obtaining 5 or more A }{ }^{*}-\mathrm{C} \\
\text { grades in the General Certificate of Secondary }\end{array}$ & & & \\
$\quad$ Education exams at age 16 & 43,469 & 0.47 & 0.21 \\
Pupil/teacher ratio & 43,514 & 16.50 & 1.65 \\
Part-time/full-time teachers & 43,510 & 0.18 & 0.12 \\
Number of pupils on school roll (in hundreds) & 43,513 & 9.54 & 3.33 \\
Proportion of pupils eligible for free school meals & 43,514 & 0.17 & 0.15 \\
Proportion of special needs pupils (with statements) & 42,986 & 0.02 & 0.02 \\
Proportion of pupils with English as second language & 43,050 & 0.01 & 0.02 \\
Proportion of pupils eligible for free school meals & & & \\
$\quad$ in other schools in district & 43,504 & 0.16 & 0.10 \\
$\quad$ Herfindahl index & 43,604 & 0.13 & 0.09 \\
Proportion of pupils obtaining 5 or more A*-C & & & \\
$\quad$ grades in other schools in the same district & 43,425 & 0.47 & 0.11 \\
Pupil/teacher ratio in district & 43,071 & 17.30 & 2.16 \\
Change in number of pupils in district (in hundreds) & 43,602 & 1.75 & 11.51 \\
\hline
\end{tabular}

Notes: The averages given are for the period 1993-2006. 